\title{
PKM STRATEGI UNTUK MEREKRUT MAHASISWA BARU DI UMN AL- WASHLIYAH MELALUI LOYALITAS ALUMNI DI KELURAHAN TUALANG KECAMATAN PERBAUNGAN KABUPATEN SERDANG BERDAGAI
}

\author{
Hardi Mulyono'), Nelvitia Purba ${ }^{2)}$, Muhammad Hilman Fikri' ${ }^{3)}$, Dedi Iskandar Batubara ${ }^{4)}$ \\ Universitas Muslim Nusantara Al-Washliyah ${ }^{1)}$ \\ Universitas Muslim Nusantara Al-Washliyah ${ }^{2)}$ \\ Universitas Muslim Nusantara Al-Washliyah ${ }^{3)}$ \\ Universitas Muslim Nusantara Al-Washliyah ${ }^{4}$ \\ hardimulyono@umnaw,ac.id, nelvitiapurba@umnaw.ac.id, hilmanfikri@umnaw.ac.id, \\ dedibatubara@umnaw.ac.id
}

\begin{abstract}
ABSTRAK
Mahasiswa yang loyal dalam hal ini alumni adalah menjadi sumber keunggulan kompetitif suatu perguruan tinggi dengan mepromosikan melalui mulut ke mulut, retensi terhadap bujukan perguruan tinggi lain dan pembelian ulang. Dengan begitu konsep mahasiswa sebagai pelanggan menekankan pentingnya bagi universitas untuk membina hubungan dua arah yang interaktif dan berbasis dialog karena keduanya terlibat secara inheren dan tak terpisahkan dalam layanan jasa. Fondasi yang diperlukan bagi Perguruan Tinggi untuk mempertahankan pelanggan yang ada adalah dengan meningkatkan pelayanan. Layanan yang buruk atau tingkat layanan yang tidak memuaskan, yang tidak dapat memenuhi harapan pelanggan dalam hal ini adalah Mahasiswa seprerti daya tarik Mahasiswa baru, yang ada, perilaku donasi, dan keanggotaan organisasi yang ada di lingkungan Universitas Dengan tingginya kepuasan mahasiswa di universitas akan memberikan implikasi berupa tingginya mahasiswa baru yang ingin kuliah di UMN Al Washliyah Medan. Permasalahan Mitra adalah Berdasarkan Wawancara Dengan Lurah Kelurahan Tualang Presentase Yang Kuliah Di UMN Al Washliyah Medan masih rendah. Dengan Berjangkitnya Covid 19 di Dunia dan tidak pengecualian di Kelurahan Tualang ini masyarakat mengalami kemerosotan Ekonomi, sehingga berpengaruh terhadap keadaan Ekonomi untuk memenuhi kebutuhan sehari - hari dan untuk melanjutkan Putra - Putrinya di Perguruan Tinggi. Belum Pernah UMN Al Washliyah Melakukan Promosi di Kelurahan Tualang ini. Belum Tersosialisasinya kemudahan-kemudahaan untuk kuliah di UMN Al-Washliyah ini di dalam menyikapi keadaan sekarang dengan berjangkitnya Virus Corona ini tanpa pengecualian di Kelurahan Tualang ini. Kegiatan pengabdian kepada masyarakat yang dilaksanakan ini di Kelurahan Tualang adalah Melalui Sosialisasi Edukasi Pentingnya PendidikanDi Masa Pandemi Covid 19 ini di Kelurahan Tualang. Sosialisasi Edukasi terkait Promosi Merekrut Mahasiswa Baru Di Kelurahan Tualang Dengan meyakinan kepada Mahasiswa Terkat Pelayanan Dan Kemudahan-Kemudahan Yang Di berikan UMN Al Washliyah Terkait Masa Pandemi Covid 19, dan ditambah lagi bahwa salah satu Pegawai di Kelurahan Tualang ini merupakan Mahasiswa UMN Al Washliyah,dan ini merupakan salah satu strategi untuk mempromosikan UMN Al Washliyah ini kepada Masyarakat Kelurahan Tualang ini.
\end{abstract}

Kata Kunci : Promosi UMN Al Washliyah, Merekrut Mahasiswa.Covid-19

\begin{abstract}
Loyal students, in this case, alumni, are a source of competitive advantage in a university by promoting by word of mouth, retention of other universities' persuasion, and repurchasing. Thus the concept of students as customers emphasizes the importance for universities to foster interactive and dialogue-based because they are both inherently and inseparably involved in service delivery. The foundation needed for Higher Education to retain existing customers is to improve services. Poor service or unsatisfactory service levels, which cannot meet customer expectations in this case are students such as the attractiveness of new students, existing donations, and membership of organizations in the university environment. High student satisfaction at the university will have implications in the form of the high number of new students who want to study at UMN Al Washliyah Medan. Partner Problems Based on Interviews with the Head of Tualang Urban Village, the percentage of those studying at UMN Al Washliyah Medan is still low. With the outbreak of Covid 19 in the world and no exception in Tualang Village, the community is experiencing an economic decline, so that it affects the economic situation to meet their daily needs and to continue their sons and daughters in higher education. Never before has UMN Al Washliyah conducted any promotions in this Tualang Village. The facilities for studying at UMN Al-Washliyah have not been socialized in responding to the current situation with the outbreak of the Corona Virus without exception in this Tualang Village. This community service
\end{abstract}


activity carried out in Tualang Village is through the Socialization of Education on the Importance of Education during the Covid 19 Pandemic Period in Tualang Village. Educational socialization related to the promotion of recruiting new students in Tualang Village by believing in the closest students to the services and conveniences provided by UMN Al Washliyah regarding the Covid 19 Pandemic, and to add that one of the employees in Tualang Village is a UMN Al Washliyah student, and This is one of the strategies to promote UMN Al Washliyah to the Tualang Village Community.

Keywords: Promotion of UMN Al Washliyah, Recruiting Students. Covid-19

\section{PENDAHULUAN}

Universitas yang merupakan sebagai perusahaan jasa maka mahasiswa juga dipandang sebagai pelanggan [1], Strategi ini merupakan satu cara untuk merekrut Mahasiswa di perguruan tinggi yaitu di UMN Al Washliyah Medan [2] Mahasiswa yang loyal menjadi sumber keunggulan kompetitif suatu perguruan tinggi dengan mepromosikan melalui mulut ke mulut, retensi terhadap bujukan perguruan tinggi lain dan pembelian ulang, dimana hal ini merupakan strategi karena salah satu Pegawai Kelurahan Tualang ini merupakan Mahasiswa UMN Al Washliyah Medan [3]. Dengan begitu konsep mahasiswa sebagai pelanggan menekankan pentingnya bagi universitas untuk membina hubungan dua arah yang interaktif dan berbasis dialog karena keduanya terlibat secara inheren dan tak terpisahkan dalam layanan jasa [4].

Dalam memenangkan persaingan tersebut peningkatan kepuasan mahasiswa perlu dilakukan sebagai Strategi promosi untuk merekrut Mahasiswa baru yang akan kulaih di UMN Al Washliyah Medan.

Kelurahan Tualang adalah merupakan salah satu Kelurahan dari 4 Kelurahan dan 24 Desa yang terdapat di Kabupaten Serdang Bedagai ,Kelurahan Tualang ini terletak di Dataran Rendah dengan ketinggian 13 Meter dari permukaan laut, dengan Suhu rata - rata $31 \mathrm{C}$ dan masuk dalam wilayah Kecamatan Perbaungan yang berjarak kira - kira 4,9 Km kearah Timur dengan luas kira - kira 598 Ha.Yang terdiri dari 11 Lingkungan dengan jumlah Penduduk sebanyak 9,335
jiwa.Banyaknya warga Kelurahan Tualang ini memberikan keragaman dalam segi Ekonomi, Sosial, Pendidikan dan sarana dan prasarana sebagai pendukung keberlanjutan Kelurahan tersebut.

Saat ini dunia diresahkan dan terguncang dengan adanya wabah Covid 19.Cepatnya sebaran virus Covid 19 sulit dibendung.Di Indonesia dengan keadaan wilayah yang besar dan masih terdapat penduduk yang terpencil dan tinggal di pedesaan memiliki kesulitan tersendiri untuk memitigasi Pandemi Covid 19 ini termasuk Keluarahan Tualang ini, dimana setiap masyarakat, termasuk juga Kelurahan Tualang ini bahwa telah terjadi perubahan pola hidup.Covid 19 ini telah merubah cara dan pola kebiasaan hidup masyarakat saat ini , Antara Lain keadaan corona ini pembelajaran bersifat konstruktivisme yang menuntut peserta didik mampu membangun pengetahuan dimana orang tua harus mampu menemani anak- anak untuk belajar secara daring,dan karena Virus Corona ini masyarakat bahkan karena keadaan ekonomi tidak mampu melanjutkan Pendidikan Putra - Putrinya di Perguruan Tinggi masyarakat dengan kemudahan -kemudahan yang diberikan UMN Al Washliyah terutama terkait pembayaran uang kuliah akan mampu membantuymasyarakat di Kelurahan Tualang ini sehingga Tahun ini juga mampu untuk melanjutkan Pendidikannya di Perguruan Tinggi

a. Berdasarkan Wawancara Dengan Lurah Kelurahan Tualang Presentase yang kuliah di UMN Al Washliyah Medan masih rendah. 
b. Dengan Berjangkitnya Covid 19 di Dunia dan tidak pengecualian di Kelurahan Tualang ini masyarakat mengalami kemerosotan Ekonomi, sehingga berpengaruh terhadap keadaan Ekonomi untuk memenuhi kebutuhan sehari - hari dan untuk melanjutkan Putra - Putrinya di Perguruan Tinggi.

c. Belum Pernah UMN Al Washliyah Melakukan Promosi di Kelurahan Tualang ini,

d. Belum TerSosialisasinya Kemudahankemudahaan untuk kuliah Di UMN Al Washliyah ini di dalam menyikapi keadaan sekarang dengan berjangkitnya Virus Corona ini tanpa pengecualian di Kelurahan Tualang ini.

\section{METODE PELAKSANAAN}

Dalam memenangkan persaingan tersebut peningkatan kepuasan mahasiswa perlu dilakukan sebagai Strategi promosi untuk merekrut Mahasiswa baru yang akan kuliah di UMN Al Washliyah Medan. Metode Pelaksanaan di dalam kegiatan ini Bermitra Antara Tim Kelurahan Tualang Dengan Tim Pengabdian Kepada Masyarakat dari Universitas Muslim Nusantara (UMN) Al Washliyah Medan dengan kegiatan kegiatannya antara lain :

1. Tahap Pendahuluan

Pada Tahapan ini Tim Pengabdi Melakukan Surat Izin Dan Surat Menyurat Dari UMN Al Washliyah Medan untuk melakukan Survey Di dalam Melaksanakan Kegiatan Abdimas ini.

2. Tim Pengabdian Masyarakat UMN Al Washliyah ini membuat Promosi dalam bentuk “ LEAFLEAT" untuk di sosialisasikan Kepada Masyarakat Kelurahan Tualang Kabupaten Serdang Bedagai sebagai salah satu Strategi untuk meyakinkan masyarakatnya sehingga memasukkan anak- anaknya untuk melanjutkan Pendidikan di Perguruan Tinggi untuk memilih UMN Al Washliyah Medan. .

3. Mengadakan Sosialisas Edukasi Tentang Pentingnya Pendidikan Untuk melanjutkan Pendidikan di Perguruan Tinggi ini dengan memberikan “ LEAFLEAT “ oleh Tim Pengabdian Masyarakat ini kepada Masyarakat di Kelurahan Tualang ini.

\section{PEMBAHASAN DAN HASIL}

Dengan banyaknya perguruan perguruan tinggi swasta di Kota Medan membuat tingkat persaingan tersebut semakin ketat. Perguruan tinggi harus mampu mengelola dengan baik perguruan tingginya termasuk UMN Al Washliyah Medan dalam hal ini menggunakan strategi pemasaran yang baik, sehingga memungkinkan mampu memenangkan tingkat persaingan dalam memperebutkan calon mahasiswa yang berasal dari berbagai SMA di Kota Medan sebagai pasar perguruan tinggi tersebut.

Mahasiswa yang loyal menjadi sumber keunggulan kompetitif suatu perguruan tinggi dengan mepromosikan melalui mulut ke mulut, retensi terhadap bujukan perguruan tinggi lain dan pembelian ulang.Dengan begitu konsep mahasiswa sebagai pelanggan menekankan pentingnya bagi universitas untuk membina hubungan dua arah yang interaktif dan berbasis dialog karena keduanya terlibat secara inheren dan tak terpisahkan dalam layanan jasa.

Dalam memenangkan persaingan tersebut peningkatan kepuasan mahasiswa sangat perlu ditingkatkan. Karena kepuasan pelanggan adalah fondasi yang diperlukan bagi perusahaan untuk mempertahankan pelanggan yang ada. 
Layanan yang buruk atau tingkat layanan yang tidak memuaskan, yang tidak dapat memenuhi harapan pelanggan, mungkin menjadi salah satu penyebab ketidakpuasan dalam pelanggan

Bahwa kepuasan mahasiswa menjelaskan sebagian besar varians dalam kemauan siswa untuk merekomendasikan institusi . Bahkan kepuasan kepuasan mahasiswa dapat meningkatkan loyalitas lain seprerti daya tarik siswa baru, retensi siswa yang ada, perilaku donasi, dan keanggotaan organisasi yang ada di lingkungan universitas . Dengan tingginya kepuasan mahasiswa di universitas akan memberikan implikasi berupa tingginya loyalitas mahasiswa yang merupakan faktor yang sangat penting bagi stabilitas fiskal kebanyakan perguruan tinggi dan universitas . Untuk itu diperlukan upaya seperti program orientasi, ekstrakurikuler, suasana akademik, pengalaman dikampus sehari- hari dalam membangun kepuasan mahasiswa yang akan meningkatkan loyalitas mahasiswa di masa depan.

Di dalam kegiatan pengabdian kepada masyarakat ini yang dilaksanakan di Kelurahan Tualang Kecamatan Perbaungan Kabupaten Serdang Bedagai pada tanggal 22 Desember 2020 ini mempromosikan UMN Al Washliyah melalui loyalitas alumninya yang ada di kelurahan ini yang nantinya akan memberikan manfaat secara sosial dan ekonomi yang pada umumnya penghasilan masyarakatnya nelayan dan petani ini diberikan oleh Tim Pengabdian UMN Al Washliyah kepada masyarakat di Kelurahan Tualang dengan memberikan promosi melanjutkan Pendidikan di UMN Al Washliyah Medan di masa pandemi Covid 19 .di samping itu masyarakat tidak boleh mengabaikan Protokol Kesehatan di dalam menjalankan kegiatan dan aktivitas sehari hari .

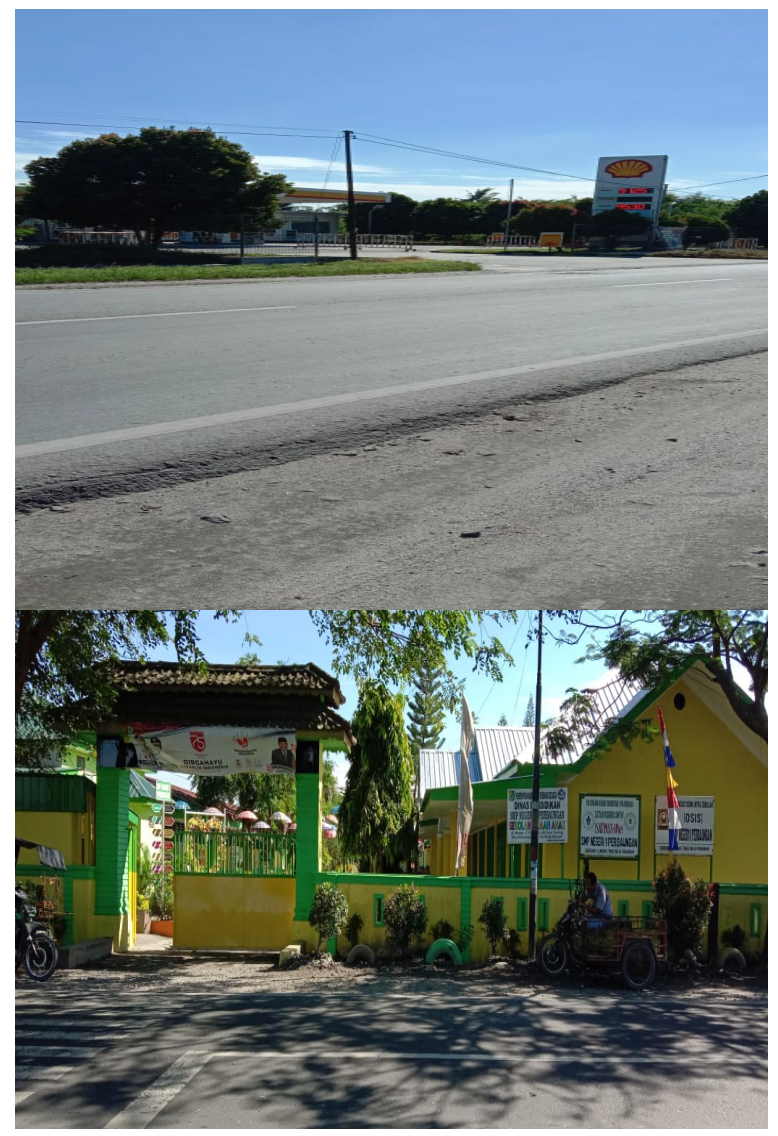

Gambar 1. Lokasi Tempat Pengabdian.

Di dalam melaksanakan kegiatan pengabdian kepada masyarakat ini memberikan manfaat secara sosial kepada masyarakat di Kelurahan Tualang ini untuk meningkatkan kualitas SDM dengan memberikan kemudahan -kemudahan untuk melanjutkan Pendidikan di UMN Al Washliyah, apalagi kegiatan pengabdian kepada masyarakat ini dibarengi dengan MOU dengan demikian di masa pandemi Covid 19 anak-anak yang ada di Kelurahan Tualang tetap bisa melanjutkan pendidikannya di masa yang sulit ini 


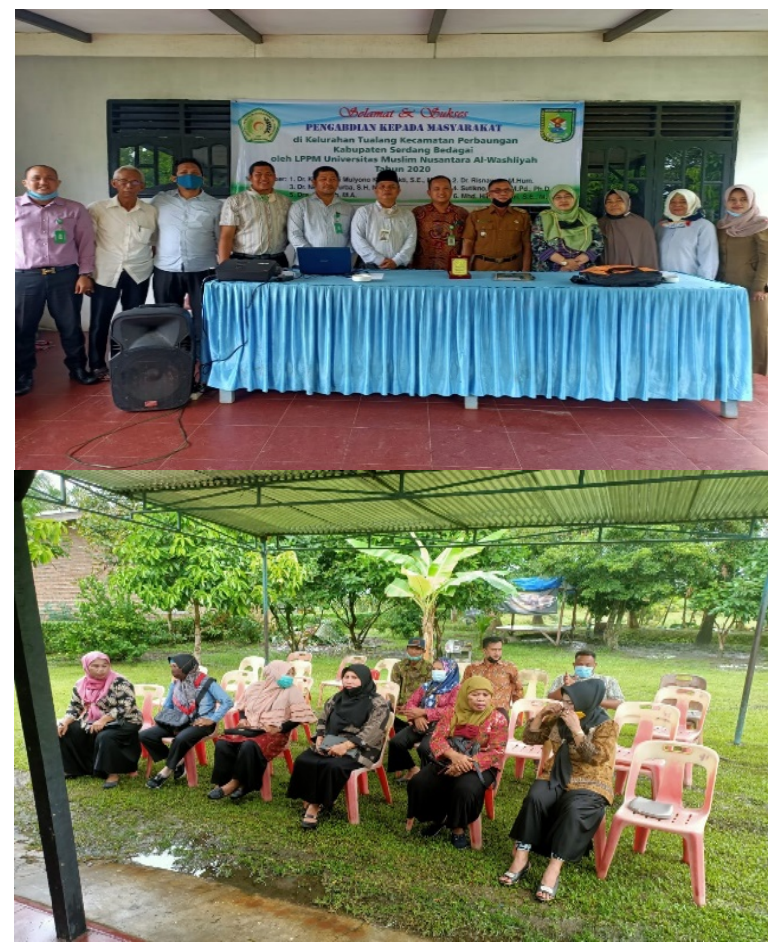

Gambar 2. Kegiatan Pelaksanaan PKM.

Di dalam kegiatan pengabdian kepada masyarakat ini peran mitra ini sangat aktif terutama pada saat pelaksanaan kegiatan tersebut,setelah tim pengabdian masyarakat mengadakan survey ketemu Lurah Kelurahan Tualang ini, beliau dan beserta stafnya yang mengkondisikan dan menghadirkan peserta dari kegiatan ini.mengingat masa pandemic Covid -19 di dalam pelaksanaan kegiatan ini tidak dilaksanakan di Kantor Lurah Tualang, namun dilaksanakan di salah satu rumah kepala lingkungan yang memiliki tempat yang terbuka untuk menjaga protokol kesehetan di dalam pelaksanaan kegiatan ini. Dalam pelaksanaan kegiatan pengabdian kepada masyarakat ini yang dilaksanakan pada tanggal 22 Desember 2020 yang bertempat di salah satu rumah kepala lingkungan pada saat pelaksanaan tidak mengalami hambatan.kendala sehingga kegiatan ini terganggu, namun gangguan yang terjadi pada saat pelaksanaan kegiatan terjadi hujan deras.Ini merupakan gangguan alam.Namun pelaksanaan kegiatan ini tetap terlaksana dengan baik.

Kegiatan pengabdian kepada masyarakat ini dapat terlaksana dengan baik karena dukungan dari semua pihak.Pada saat pelaksanaan kegiatan ini juga penandatanganan MOU yang diwakili oleh Wakil Rektor III, dimana kelurahan Tualang ini jadi mitra dan Desa Binaan dari Universitas Muslim Nusantara Al Washliyah Medan.

Untuk keberlanjutan dari kegiatankegiatan terkait pengabdian masyarakat maka Kelurahan Tualang ini merupakan Desa Binaan dari UMN Al Washliyah, untuk itu keberlanjutan dari kegiatan-kegiatan akan rutin di laksanakan di kelurahan ini.

\section{KESIMPULAN}

Dengan mewabahnya pandemic Covid 19 di dunia pada umumnya dan khususnya di Indonesia ini termasuk Keluarahan Tualang ini, dimana setiap masyarakat telah terjadi perubahan pola hidup karena .Covid 19 yakni telah merubah cara dan pola kebiasaan hidup masyarakat saat ini ,dengan adanya Virus Corona ini masyarakat prihatin karena keadaan ekonomi tidak mampu untuk melanjutkan Pendidikan Putra - Putrinya di Perguruan Tinggi .oleh karena itu melalui pdngabdian kepada masyarakat di kelurahan Tualang ini yang ada beberapa alumni berasal dari daerah ini dalam rangka untuk memberdayakan alumni terkait loyalitas mempromosikan UMN Al Washliyah ke masyarakat dengan kemudahan -kemudahan yang diberikan UMN Al Washliyah terutama terkait pembayaran uang 
kuliah sehingga membantu masyarakat di Kelurahan Tualang ini tahun ini mampu untuk melanjutkan Pendidikannya di Perguruan Tinggi.

\section{REFERENSI}

Abdullah, F. (2006). The development of HEdPERF: a new measuring instrument of service quality for the higher education sector. International journal of consumer studies, $\quad 30(6), \quad 569-581$. doi:10.1111/j.14706431.2005.00480.x

Al-Alak, B. A. M. (2006). The impact of marketing actions on relationship quality in the higher education sector in Jordan. Journal of Marketing for Higher Education, 16(2), 1-23. doi:10.1300/J050v16n02_01

Alves, H., dan Raposo, M. r. (2010). The influence of university imageon student behaviour. International Journal of Educational Management, 24(1), 73-

85. doi:10.1108/09513541011013060 Anderson, J. E. (2015). Public Policymaking: An Introduction (Eighth ed.).

Stamford, USA: Cengage Learning.

Bowden, J. L.-H. (2011). Engaging the Student as a Customer: A Relationship Marketing Approach. Marketing Education Review, 21(3), 211-228. doi:10.2753/MER10528008210302

Brochado, A. (2009). Comparing alternative instruments to measure service quality in higher education. Quality assurance in Education, 17(2), 174190.

doi:10.1108/09684889510093497

Burrow, J. L., Kleindl, B., dan Everard, K. E. (2008). Business Principles and Management. nited States of America: Thomson SouthWestern

Hardi Mulyono,Arief Hadian,Nelvitia Purba,Rudy Pramono, (2020),Effect Service Quality Toward.Student Satisfaction And Loyalty In Higher Education, Journal Of Asian Finance,Economics And Business. 